Wen et al., Afr J Tradit Complement Altern Med. (2014) 11(1):131-134

http://dx.doi.org/10.4314/ajtcam.v11i1.20

\title{
EXPERIMENTAL STUDY ON THE INHIBITORY EFFECT OF SODIUM CANTHARIDINATE ON HUMAN HEPATOMA HEPG2 CELLS
}

\author{
Shi-Qi Wen", Quan Chen, Ming Hu \\ Department of Vascular, Gansu Provincial Hospital, Lanzhou 730000, China \\ *E-Mail: jlknewkln@126.com
}

\begin{abstract}
Backgroud: Cantharidin, and its derivatives can not only inhibit the proliferation of tumor cells, but can also induce tumor cell apoptosis. It shows cantharidin exhibits a wide range of reactivity in anticancer. The objective of this paper was to study the inhibitory effect of sodium cantharidinate on human hepatoma HepG2 cells.
\end{abstract}

Materials and Methods: MTT assay was used to detect the proliferation of HepG2 cells, and immunohisto-chemical method was used to detect the change in VEGF, protein level, and to determine the inhibitory effect of sodium cantharidinate on human hepatoma HepG2 cells.

Results: As results, sodium cantharidinate significantly inhibited the growth of HepG2 cells in a time-and dose-dependent manner.

Conclusion: We conclude that sodium cantharidinate has an inhibitory effect on human hepatoma HepG2 cells.

Key words: sodium cantharidinate; human hepatoma HepG2; MTT assay

\section{Introduction}

Ban Mao is the dried body of Meloidae insects Mylabris phalerata Pallas or Mylabris cichorii Linnaeus, which has the effects of counteracting toxic substances, and eliminating phagedena, dispelling stasis and dissipating stagnation. The main active ingredient of Ban Mao is cantharidin, and its derivatives include norcantharidin, sodium cantharidinate and dehydronorcantharidin, etc. Cantharidin and its derivatives can not only inhibit the proliferation of tumor cells, but can also induce tumor cell apoptosis (Zhang et al., 2005; An et al., 2005; Huh et al., 2004; Efferth et al., 2005). In this study, sodium cantharidinate acted on hepatoma HepG2 cells, apoptosis characteristics of tumor cells were dynamically observed, and the possible mechanism for its effect on growth of HepG2 cells studied.

\section{Materials and methods}

Drugs and reagents

Human hepatoma cell line (HepG2), purchased from the National Cell Bank of Shanghai Cell Institute of CAS; MTT (Amresco, USA); IX70, inverted microscope (Olympus), sodium cantharidinate injection (Guizhou Maqika Pharmaceutical Co., Ltd. No. H52020601), RPMI-1640 culture medium (Hyclone, USA); fetal bovine serum (Lanzhou National Hyclone Bio-Engineering Co., Ltd.).

\section{Cell cultivation}

The human hepatoma HepG2, cells were seeded in 100ml, glass flasks, grown adherently in RPMI-1640, medium containing 10\%, fetal bovine serum, and then placed and cultured in an incubator set at $37^{\circ} \mathrm{C}$, with $5 \% \mathrm{CO}_{2}$ and saturated humidity. Cells were grown adherently, the medium was replaced every 1-2, days, and the cells were passaged once every 2 days.

\section{Detection of cell proliferation by MTT assay}

Cells in the logarithmic growth phase were taken and digested with $0.25 \%$ trypsin, stained with trypan blue and then counted. The concentration of the live cell suspension was adjusted to $1 \times 10^{5}$ cells $/ \mathrm{ml}$ for later use. 
http://dx.doi.org/10.4314/ajtcam.v11i1.20

Detection of cell proliferation by MTT assay

The cell suspension was taken and seeded in 96 , well plates at $100 \mu \mathrm{l}$ per well, incubated in RPMI-1640, medium for $24 \mathrm{hrs,} \mathrm{after} \mathrm{most}$ cells grew adherently, the culture medium was discarded. The experiment had five groups: blank control group, cell control group and sodium cantharidinate groups, the blank control group was distilled water, drug concentrations of sodium cantharidinate groups were: 1,2 , and $3 \mu \mathrm{g} / \mathrm{ml}$, respectively. After cells were adherent, culture medium was replaced with fresh medium containing different concentrations of sodium cantharidinate, and the cells were incubated in a $37^{\circ} \mathrm{C}$, incubator for 24,48 , and $72 \mathrm{hrs}$, respectively, then drug solution and culture medium were discarded, $20 \mu \mathrm{l}$ of MTT ( $5 \mathrm{~g} / \mathrm{L})$, was added to each well, and the cells were cultured for another $4 \mathrm{hrs}$, then drug solution and culture medium were discarded, and $150 \mu \mathrm{l}$ of DMSO was added, after shaken uniformly, optical density (OD), value of each well was measured at a 490nm wavelength using a micro-plate reader, averaged, and the cell proliferation inhibition rate was calculated.

Cell proliferation inhibition rate $(\mathrm{IR})=(1$ - OD experimental group / OD control group $), \times 100 \%$.

\section{Detection of VEGF protein expression by immunohisto-chemical method}

Hepatoma cells in the logarithmic growth phase were taken, digested with $0.25 \%$ trypsin, and then prepared into cell suspension with a concentration of $1 \times 10^{4} \mathrm{cell} / \mathrm{ml}$, and seeded in culture plates, after $24 \mathrm{hrs}$, when the cells were adherent, the culture medium was discarded, and the control group and experimental groups were added with corresponding culture mediums at $2 \mathrm{ml}$ per well. Cells in the four groups were cultured in an incubator set at $37^{\circ} \mathrm{C}$ with $5 \% \mathrm{CO}_{2}, 48 \mathrm{hrs}$, later, the growth of the hepatoma cells were observed under an inverted microscope. The integrated optical density (IOD), value of VEGF, protein expression was analyzed according to the immunocyto-chemical staining procedure. The larger the value of IOD; the higher the expression quantity of the target protein.

\section{Statistical analysis}

All data were expressed as mean \pm standard deviation $(\mathrm{x} \pm \mathrm{s})$, and analyzed using SPSS 15.0 statistical software.

\section{Results}

\section{Growth curve of HepG2 cells}

As can be seen from Fig. 1, HepG2 cells grew relatively slow just after seeding, $24 \mathrm{~h}$ later, a clear proliferation of cells was seen. Between 2-4 d after inoculation, the cells were in the exponential growth phase, where they grew abundantly, between 5-6 days, cell growth rate decreased significantly compared with the previous phase, which approached the plateau phase.

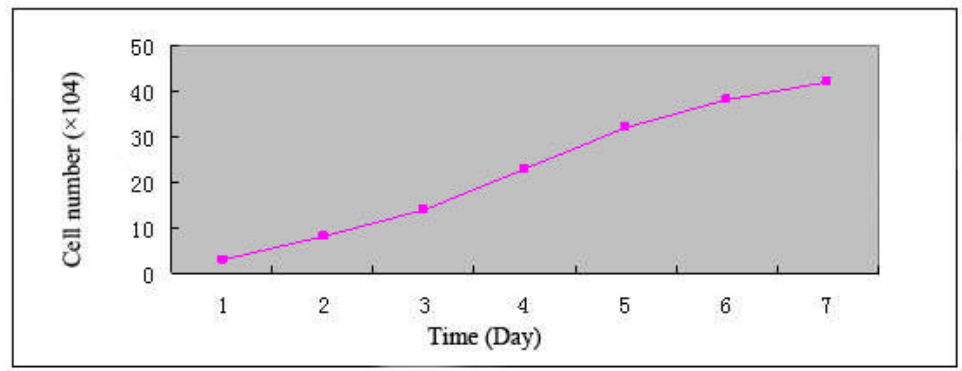

Figure 1: Growth curve of hepatoma HepG2 cells

\section{MTT assay results}

The MTT assay results indicated that sodium cantharidinate has a significant inhibitory effect on the growth of HepG2 cells, which was time-and dose-dependent. At 24hrs, the cell inhibition rates of 3, doses were 46.01\%, 29.75\%, and 15.07\% in decreasing order of concentration; while at $72 \mathrm{hrs}$, inhibition rate of each dose rose to $58.13 \%, 35.37 \%$, and $26.01 \%$, respectively. 
Wen et al., Afr J Tradit Complement Altern Med. (2014) 11(1):131-134

http://dx.doi.org/10.4314/ajtcam.v11i1.20

Detection of VEGF expression in HepG2 cell lines by immunohisto-chemical method

It was observed under an electron microscope that the positive expression of VEGF protein in hepatoma cells was brownish yellow granules, compared with the control group, the brownish yellow granules were reduced, and lightly stained in the cytoplasm of the experimental groups, and the effect was inversely proportional to the concentration of the drug, as shown in Figure 2.

Table 1: HepG2 cell survival rate after intervention of sodium cantharidinate for different times

\begin{tabular}{|c|c|c|c|c|c|c|}
\hline \multirow[b]{2}{*}{ Group } & \multicolumn{2}{|c|}{$24 \mathrm{~h}$} & \multicolumn{2}{|c|}{$48 \mathrm{~h}$} & \multicolumn{2}{|c|}{$72 \mathrm{~h}$} \\
\hline & OD value & $\begin{array}{l}\text { Inhibition } \\
\text { rate }(\%)\end{array}$ & OD value & $\begin{array}{l}\text { Inhibition } \\
\text { rate }(\%)\end{array}$ & OD value & $\begin{array}{l}\text { Inhibition } \\
\text { rate }(\%)\end{array}$ \\
\hline Control group & $0.763 \pm 0.012$ & & $0.647 \pm 0.005$ & & $0.523 \pm 0.003$ & \\
\hline $\begin{array}{c}\text { Sodium cantharidinate } \\
\text { group } \\
(1 \mu \mathrm{g} / \mathrm{ml})\end{array}$ & $0.648 \pm 0.003$ & 15.07 & $0.519 \pm 0.003$ & 19.79 & $0.387 \pm 0.009$ & 26.01 \\
\hline $\begin{array}{c}\text { Sodium cantharidinate } \\
\text { group } \\
(2 \mu \mathrm{g} / \mathrm{ml})\end{array}$ & $0.536 \pm 0.005$ & 29.75 & $0.447 \pm 0.003$ & 30.92 & $0.338 \pm 0.003$ & 35.37 \\
\hline $\begin{array}{c}\text { Sodium cantharidinate } \\
\text { group } \\
(3 \mu \mathrm{g} / \mathrm{ml})\end{array}$ & $0.412 \pm 0.012$ & 46.01 & $0.317 \pm 0.001$ & 51.01 & $0.219 \pm 0.007$ & 58.13 \\
\hline
\end{tabular}

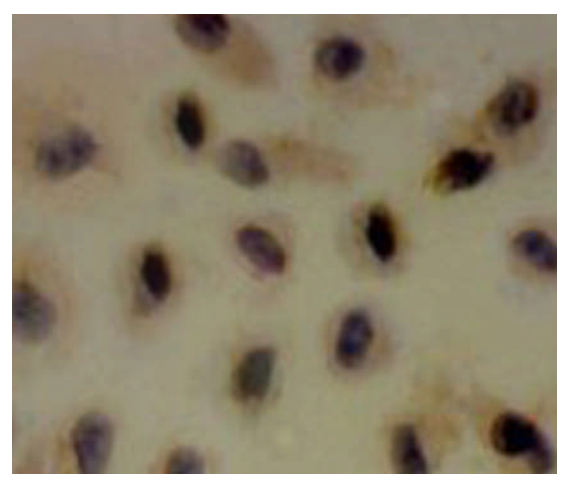

Control group

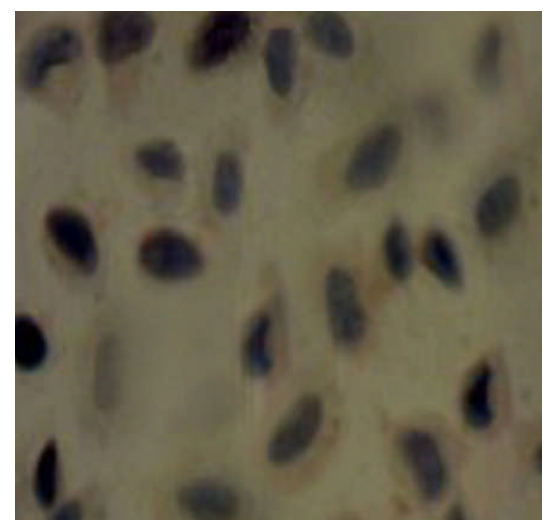

Sodium cantharidinate medium concentration group

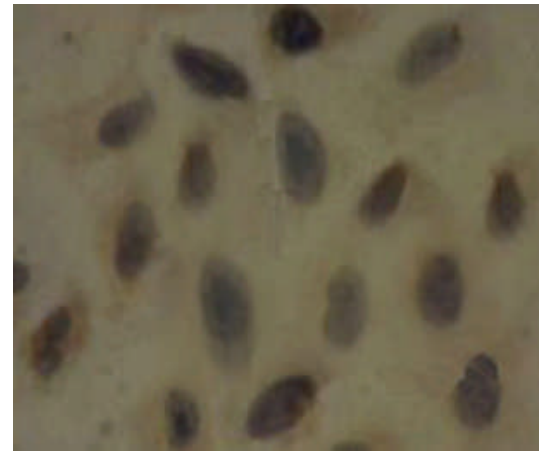

Sodium cantharidinate low concentration group

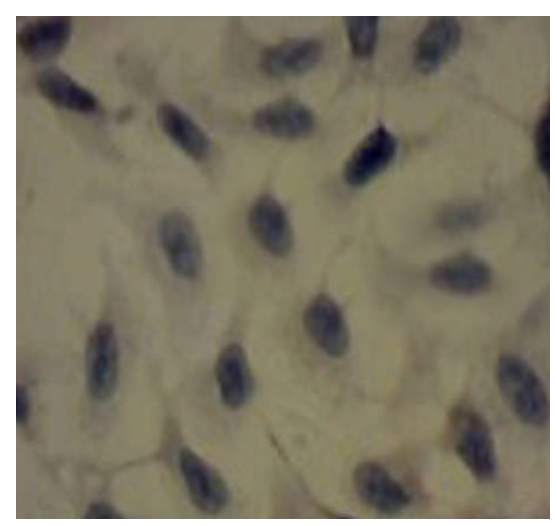

Sodium cantharidinate high concentration group

Figure 2: Differences in expression of VEGF protein in different experimental groups 
http://dx.doi.org/10.4314/ajtcam.v11i1.20

\section{Discussion}

Primary hepatocellular carcinoma (PHC), is one of the most common malignant tumors, its mortality ranks third among malignant tumors, nearly a million people die from hepatocellular carcinoma every year. The incidence of hepatocellular carcinoma is relatively high in China, accounting for approximately 55\% of the world's new hepatocellular carcinoma cases. Among the new cases of hepatocellular carcinoma, the majority of patients were co-infected with hepatitis B and hepatitis C viruses, and the incidence tends to be higher with the increase of age (Luo et al., 2008).

Modern medical procedures for the treatment of hepatocellular carcinoma include resection, transplantation and various local ablations, etc. Clinically, the combination of various therapies is applied more extensively in the treatment of middle and advanced hepatocellular carcinomas, of which the antineoplastic drugs can prolong life of patients and improve their quality of life.

Cantharidin is a chemical substance extracted and purified from the medicinal materials of blister beetle, it is highly toxic, trace amount of cantharidin can cause mucosal blistering; its clinical use has therefore been largely restricted (Yu et al., 2007; Saradha et al., 2009; Dey et al., 2009). Sodium cantharidinate is produced by the hydrolysis of cantharidin with sodium hydroxide, which not only reduces the toxic side effects of cantharidin, but also enhances its anti-tumor effect.

This study explored the mechanism of action of sodium cantharidinate on human hepatoma HepG2 cells, and observed its inhibitory effect on hepatoma cell proliferation, which showed time- and dose-dependence. After $24 \mathrm{~h}$ of action on human hepatoma HepG2 cells, the cell inhibition rates of three doses were $46.01 \%, 29.75 \%$, and $15.07 \%$ in decreasing order of concentration; while at $72 \mathrm{hrs}$, the inhibition rate of each dose rose to $58.13 \%, 35.37 \%$, and $26.01 \%$, respectively.

\section{References}

1. An WW, Wang MW, Gong XF, Tian DZY, Xiao YSM, Chi DQ. (2005) Norcantharidin induces HeLa cells apoptosis through caspases pathway. Chinese Journal of Pathophysiology, 21: 417-421

2. Dey S, Guha M, Alam A, Goyal M, Bindu S, Pal C, Maity P, Mitra K, Bandyopadhyay U. (2009) Malarial infecfion develops mitochondrial pathology and mitochondrial oxidative stress to pmomote hepatocyte apoptosis. Free Radic BiolMed, 46: 271-281

3. Efferth T,Rauh R,Kahl S, Tomicic M, Böchzelt H, Tome ME, Briehl MM, Bauer R, Kaina B. (2005) Molecular modes of actionof cantharidin in tumor cells. Biochem Pharmacol, 69: 811-818

4. Gui YS, Cao XY, Chen Q. (2004) Experimental Study of Human Hepatocellular Carcinoma Cells Apoptosis Induced with Sodium Cantharidate in vitro. Medical Journal of Wuhan University, 25(5): 493-496

5. Huh JE, Kang KS, Chae C, Kim HM, Ahn KS, Kim SH. (2004) Roles of p38 and JNK mito gen activated protein kinase pathways during cantharidin induced apoptosis in U937 cells. Biochem Pharmacol, 67: 1811-1818

6. Luo D, Ye LH. (2008) Current situation and prospects of experimental researches on treatment of hepatoma using traditional Chinese herbs. World Chinese Journal of Digestology, 16: 2964-2968

7. Rauh R, Kahl S, Boechzelt H, Bauer R, Kaina B, Efferth T. (2007) Molecular biology of cantharidin in cancer cells. Chin Med, 4: 2-8

8. Saradha B, Valthinathan S, Mathur PP. (2009) Lindane induces testicular apoptosis in adult W istar rats through the involvementofFas-FasL and mitochondria-dependent pathways. Toxicology, 255: 131-139

9. Yu J, Wang P, Ming L, Wood MA, Zhang L. (2007) SMAC/Diablomediates the proapoptotic function of PUMA by regulatingPUMA-inducedmitochondrial events. Oncogene, 26: 4189-4198

10. Zhang WD, Zhao HN, Yan Y, Wang XH, Zong ZH, Liu Y. (2005) Apoptosis induced by cantharidin in human pulmonary carcinoma cells A549 and its molecular mechanisms. Chinese Journal of Oncology, 27: 330-334 